\title{
Leszek Żyliński
}

\section{Zdzisław Żygulski - twórca powojennej germanistyki polskiej}

ziejów polskiej germanistyki historycznoliterackiej, szczególnie jej okresu powojennego, nie sposób napisać, nie wymieniając nazwiska profesora Zdzisława Żygulskiego. Przyszły uczony urodził się 4 kwietnia 1888 roku w Przemyślu w rodzinie kolejarskiej; matka Wanda Sądecka miała pochodzenie ziemiańskie. Do szkoły powszechnej chodził w Tarnopolu (1894-1898), do gimnazjum natomiast w Samborze (1898-1903) i we Lwowie (1903-1906), gdzie w 1906 roku uzyskał maturę. W tym samym roku zapisał się na Uniwersytet Jana Kazimierza, wybierając jako główny przedmiot studiów germanistykę, a poboczny filologię polską.

Swoje lwowskie studia barwnie wspominał Profesor w opublikowanym tekście autobiograficznym, wydanym z okazji 45-lecia pracy naukowej. Ponieważ sam opis studiowania przed ponad stu laty jest dla współczesnych ciekawym dokumentem $\mathrm{z}$ historii nauki, pozwalam sobie przytoczyć dłuższy wyimek z owego wspomnienia.

Jako student lwowskiej germanistyki w latach 1906-1908 uczęszczałem na wykłady i seminaria [Richarda Marii] Wernera oraz [Josepha] Schatza. Pierwszy czytał z nami utwory Goethego - przede wszystkim liryki - a drugi interpretował teksty gockie i starogórnoniemieckie. Jego wykłady z gramatyki były blade i bezbarwne. Własnych koncepcji nie posiadał.

Ówczesny system naukowy na uniwersytetach różnił się oczywiście bardzo od dzisiejszego. Nie było podziału kursowego i wszyscy studenci, starsi i młodsi, uczęszczali na te same wykłady i na te same seminaria. Nie było też - co dziś wydaje się nieprawdopodobne - sił pomocniczych, tj. asystentów. Ci istnieli tylko przy katedrach fizyki i chemii na politechnikach i na medycynie. Na wydziałach humanistycznych profesor był sam sobie 'sterem, żeglarzem, okrętem', aby użyć słów poety. Wykładał, egzaminował, prowadził seminaria, czytał i poprawiał niezliczone prace seminaryjne, doktorskie, kandydackie. Katedra lwowskiej germanistyki nie posiadała wówczas własnej biblioteki, ani odrębnego pomieszczenia, a studenci mieli do dyspozycji tylko - bardzo zresztą zasobną - bibliotekę uniwersytecką. $\mathrm{W}$ ciągu czterech lat studiów nie byli obowiązani do zdawania egzaminów, mogli natomiast co półrocza zdawać kolokwium z wysłuchanego 


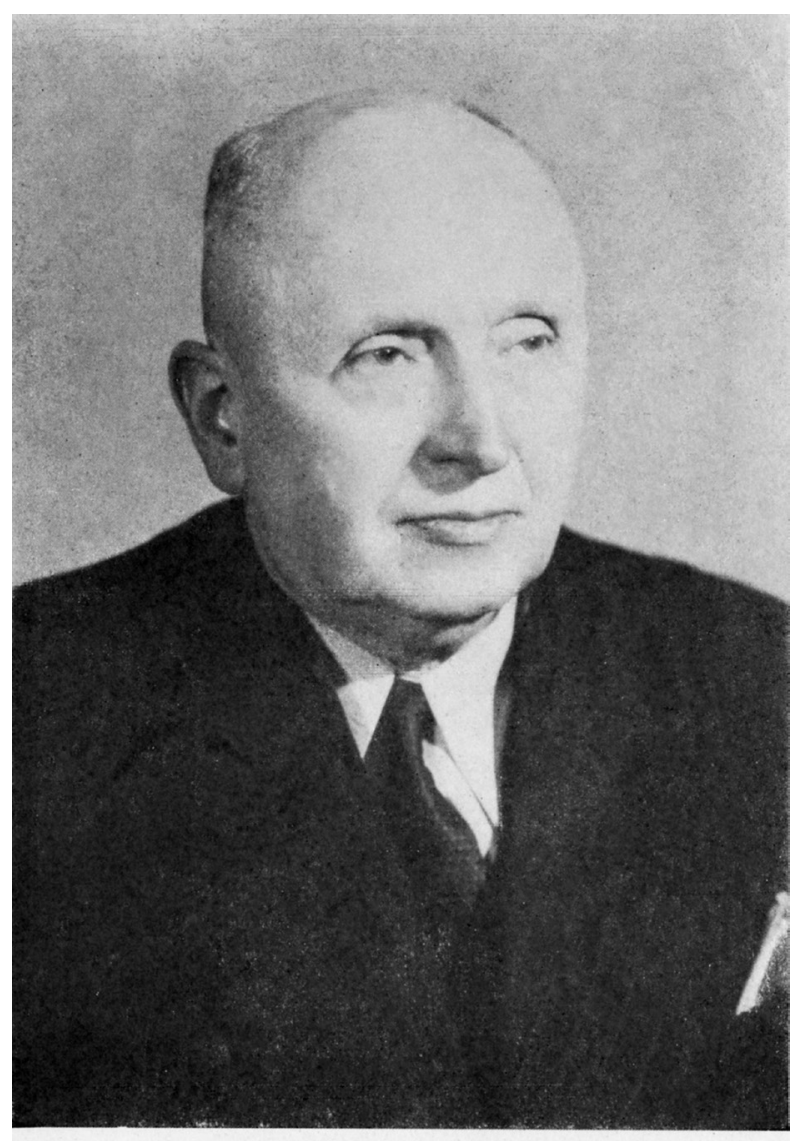

$$
\text { Is Zdristaw Zyguly }
$$

wykładu. Musieli też uczęszczać na seminaria, wygłaszać tam referaty i pisać prace. Dopiero po czterech latach studiów można było uzyskać doktorat filozofii, jak się to wówczas nazywało, na podstawie napisanej rozprawy (dysertacji) i po złożeniu dwóch bardzo trudnych egzaminów komisyjnych, tzw. rygorozów. Jeden z tych egzaminów obejmował całokształt wiedzy germanistycznej (język i literaturę), a drugi był poświęcony specjalnie filozofii. W celu uzyskania stopnia nauczyciela gimnazjalnego należało zdać bardzo trudny i skomplikowany egzamin kandydacki, obejmujący obok przedmiotu głównego kilka przedmiotów pobocznych. Tego egzaminu wielu kandydatów nigdy nie zdało i ci uczyli przez całe życie w szkole średniej jako „zastępcy nauczycieli", popularnie zwani suplentami, bez prawa do awansu i do emerytury. Wymagania przy egzaminach były duże. Jeśli chodzi o germanistykę, to główny nacisk kładziono na gramatykę historyczną (tak jak ją wtedy rozumiała szkoła tzw. „junggramatyków”) i na interpretację starych tekstów. Kandydat musiał znać doskonale język gocki oraz staro- i średnio-górnoniemiecki. Gramatyki opisowej - poza składnią - prawie nie pytano uważając, że absolwent klasycznego gimnazjum zna ją na wylot. Z historii literatury główną wagę przykładano do literatury średniowiecznej (do roku 1250) oraz do literatury nowszej od wystąpienia Gottscheda aż do 
śmierci Goethego. Te okresy pytano bardzo szczegółowo, przykładając szczególną wagę do dat, życiorysów, genezy i powstawania poszczególnych utworów, ich różnych redakcji, treści i formy. Strona ideologiczna tylko mało była brana w rachubę. Najbardziej „żyłowanymi” autorami byli z dawnej kultury Wolfram [von Eschenbach] i Walther [von der Vogelweide], a z nowszej Klopstock, Lessing, Goethe i Schiller. Romantyzmem przeważnie nie zajmowano się bliżej. Zależało to zresztą od upodobań odnośnego profesora. Literatury XIX w. od śmierci Goethego - poza Grillparzerem - na ogół nie pytano. Czasem tylko padało pytanie z Heinego lub z Młodych Niemiec.

Studenci byli zdani głównie na własne siły. Musieli dużo czytać i zaznajomić się z ogromnym materiałem, który na wykładach poznawali tylko częściowo. Wymagano też od nich dobrej znajomości laciny, greki i historii. Należy jednak podkreślić, że w tej dziedzinie otrzymywali już bardzo dobre przygotowanie w gimnazjum. Nawet przeciętnie zdolny abiturient czytał bez trudności w oryginale dzieła Ksenofonta, Homera, Platona, Cycerona, Liwiusza, Wergilego i innych klasycznych autorów.

W czasie, w którym uczęszczałem na uniwersytet lwowski, było tam sporo bardzo zdolnych studentów, z których wielu zabłysnęło potem w nauce i zajmowało katedry uniwersyteckie. Moimi rówieśnikami, względnie starszymi kolegami byli: Juliusz Kleiner, wybitny polonista, autor znanych monografii o Słowackim i o Mickiewiczu, zajmujący się też literaturą niemiecką (wydał interesujący zbiór studiów pt. $W$ kręgu Mickiewicza i Goethego), Zygmunt Łempicki, pierwszy i jak dotąd jedyny germanista uniwersytetu warszawskiego; jego stryjeczny brat Stanisław historyk oświaty, Stanisław Kot - badacz dziejów reformacji w Polsce, Zygmunt Czerny - profesor romanistyki, Tadeusz Dąbrowski - przedwcześnie zmarly - doskonale zapowiadający się krytyk; Stanisław Wasylewski - znany literat i eseista i wielu innych, których działalność naukowa, literacka czy też publicystyczna nie przeszła bez echa ${ }^{1}$.

Studia germanistyczne kontynuował Żygulski w latach 1908-1912 na Uniwersytecie Wiedeńskim, a wśród jego nauczycieli byli m.in. Jakob Minor, Joseph Seemüller czy późniejszy promotor jego doktoratu Alexander Weil von Weilen. Rozprawę doktorską pt. Die Gleichnisse in Goethes Gesprächen broni tuż przed wybuchem pierwszej wojny światowej, natomiast już od roku 1912 pracuje jako nauczyciel języka niemieckiego w różnych szkołach na terenie ówczesnej Galicji. W roku 1929 otrzymuje tytuł profesora gimnazjalnego, pracując do roku 1940 w Państwowym III Gimnazjum im. Stefana Batorego we Lwowie. Krótko przed wybuchem drugiej wojny światowej zdążył Żygulski uzyskać we Lwowie habilitację na podstawie opublikowanej później pracy Schillers tragisches Pathos. Sein Ursprung und seine Ausdrucksmittel (1939). W tym samym roku w serii Archiwum Towarzystwa Naukowego we Lwowie ukazała się kolejna jego książka pt. Tragedie Seneki a dramat nowożytny do końca XVIII wieku, pomyślana jako część pierwsza obszernego opracowania. W latach 20. i 30. publikował Żygulski studia dotyczące weimarskich klasyków i dramatu nowożytnego, a w serii „Biblioteki Narodowej” Ossolineum wydał opracowane przez siebie dramaty Schillera Zbójcy (1923) i Dziewica Orleańska (1928). Jego artykuł z 1932 roku o francuskiej filiacji dramatu barokowego poety Andreasa Gryphiusa zdradza komparatystyczne zacięcie badawcze, wielojęzyczną erudycję autora i jest do dziś jego „najżywiej recypowaną pracą w przestrzeni międzynarodowej”2. Prace Żygulskiego z tamtego okresu „są dokładne i inno-

Z. Żygulski, Garść wspomnień, "Germanica Wratislavienia” III, Wrocław 1959, s. 8-10.

2 W. Kunicki, Zdzisław Żygulski (1888-1975), [w:] Germanistik in Polen. Zur Fachgeschichte einer literaturwissenschaftlichen Auslandsgermanistik - 18 Porträts, Hrsg. W. Kunicki, M. Zybura, Osnabrück 2011, s. 96. 
wacyjne, a do tego napisane klarownym językiem niemieckim odpowiadają całkowicie poziomowi ówczesnych badań” ${ }^{3}$. W tym okresie był on zresztą nie tylko prywatnym uczonym i nauczycielem, pisał również krytyczne teksty do lwowskich gazet, a w latach 30. zasiadał w lwowskiej radzie miasta.

Wspaniale zapowiadającą się karierę naukową przerwała wojna. Żygulski pozostaje we Lwowie, pracując na Uniwersytecie w czasach, gdy miastem rządzą Sowieci, czy też imając się różnych zajęć w okresie niemieckiej okupacji miasta. Jak pisze jego uczennica, późniejsza profesor Anna Stroka, wraz z „okupacją niemiecką dla Zdzisława Żygulskiego zaczął się najcięższy okres. Przez czas jakiś był bez zajęcia w bardzo trudnych warunkach materialnych. Pracę znalazł wreszcie jako nauczyciel”, a następnie „korespondent w przedsiębiorstwie handlowym”" We wrześniu 1945 roku decyduje się opuścić Lwów i obejmuje stanowisko profesora nadzwyczajnego na tworzonym Uniwersytecie Łódzkim. Tam organizuje katedrę i kształcenie na kierunku filologii germańskiej. Podczas aktywności w Łodzi pełni Żygulski obowiązki prodziekana Wydziału Humanistycznego nowego uniwersytetu, pracuje jednocześnie w nowo powstałej Wyższej Szkole Teatralnej, będąc jej prorektorem, a po odejściu Leona Schillera do Warszawy przez krótko rektorem. Jego pierwszego germanistycznego wykładu poświęconego niemieckiej literaturze średniowiecznej słuchało dziewięcioro studentów. Lata powojenne ze zrozumiałych względów nie sprzyjają studiowaniu mowy i kultury niemieckiej, tym bardziej że już kilka lat później zamkniętych zostaje większość katedr neofilologicznych w Polsce. Germanistykę można było uprawiać i studiować jedynie w Poznaniu i we Wrocławiu. Tam też w roku 1952 zostaje przeniesiony prof. Żygulski.

Okres wrocławski jest najbardziej twórczym i spełnionym w naukowym życiu Profesora. W latach 1952-1960 kieruje Katedrą Filologii Germańskiej, budując na tym Uniwersytecie silną pozycję badań nad literaturą baroku oraz włączając się w rozwijane we Wrocławiu studia śląskie. Jeszcze w Łodzi zdążył wypromować późniejszego kierownika tamtejszej germanistyki, prof. Arno Willa, ale we Wrocławiu ze szkoły profesora Żygulskiego wychodzi cała plejada uczniów, którzy następnie tworzyli ośrodki badań i kształcenia germanistycznego na wielu polskich uniwersytetach. Do wrocławskich uczniów Żygulskiego należą m.in. tak wybitni literaturoznawcy jak Marian Szyrocki, Eugeniusz Klin, Gerard Koziełek, Anna Stroka czy Norbert Honsza. Jego wpływ wykraczał zdecydowanie poza ośrodek wrocławski; jak twierdzi przywoływana już Stroka, Żygulski „recenzował prawie wszystkie prace habilitantów innych ośrodków"s.

Kolejnym jego osiągnięciem stało się uruchomienie pierwszego i na długie lata jedynego naukowego periodyku germanistycznego, jaki od 1958 roku stanowiła „Germanica Wratislaviensia”. Również w tych zeszytach ukazywały się studia nad piśmiennictwem śląskim okresu baroku, dziedziną w której zasoby wrocławskich bibliotek otworzyły uczniom Żygulskiego drzwi do niemieckiej i światowej germanistyki. Już w 1957 roku wraz z Szyrockim wydał Żygulski antologię Silesiaca ${ }^{6}$. Przynosiła ona ważne teksty pisarzy śląskich, niekiedy dotychczas

\footnotetext{
3 Ibidem, s. 98. Tłumaczenie - L. Ż.

${ }^{4}$ A. Stroka, Życie i działalność naukowa Zdzisława Żygulskiego, [w:] Z dziejów germanistyki historycznoliterackiej w Polsce. Studia i materiały, Łódź 1991, s. 65-77, tu s. 67.

5 Ibidem, s. 76.

6 M. Szyrocki, Z. Żygulski, Silesiaca. Wybór dzieł pisarzy śląsko-niemieckich XVII wieku w tekstach oryginalnych i polskich przekładach, Warszawa 1957.
} 
nieznane. Jej wartość leżała ponadto w niezwyczajnej wówczas postawie badawczej, która łączyła język niemiecki i polski (przekłady), dowartościowywała niemiecką twórczość powstałą na Śląsku (wbrew forsowanej tezie o wyłącznie piastowskim rodowodzie tej ziemi) oraz wyłamywała się z powtarzanych schematów poprawności politycznej wczesnego PRL, gdzie wszelkie ślady niemieckie chciano widzieć tylko jako skutki polityki germanizacyjnej. Również na polu badań nad literaturą niemieckiego romantyzmu odegrał Żygulski pionierską rolę, pozbawiając ją w swych pracach stygmatu reakcjonizmu, jaki dominował wówczas w retoryce literaturoznawstwa marksistowskiego. Jak stwierdza Wojciech Kunicki, „nie uwzględniając specyficznych enerdowskich wytycznych wobec romantyzmu, we Wrocławiu mogły rozwinąć się badania nad romantyzmem nawiązujące do germanistyki zachodnioniemieckiej”, a podsumowując całą aktywność naukową i organizacyjną Profesora, pisze, że „germanistyka wrocławska dzięki Żygulskiemu mogła w ogóle przetrwać ciężkie czasy stalinowskie"

Jako student germanistyki autor niniejszego portretu rozpoczął w połowie lat 70. zgłębianie literatury niemieckiej, opierając się na podręczniku, na którym wychowało się całe pokolenie polskich germanistów. Czterotomowa, napisana po niemiecku historia literatury Szyrockiego i Żygulskiego stanowiła - choćby wobec braku innych opracowań - podstawową lekturę towarzyszącą poznawanym autorom, prądom i epokom. Trzeci i czwarty tom owego skryptu opracował właśnie Zdzisław Żygulski. Dzisiaj ta praca nie sprostałaby wymogom współczesnej nauki, ale jeszcze w latach 70. (wtedy ukazało się jej trzecie wydanie) przy swym metodologicznym konserwatyzmie raczej zachęcała do zgłębiania niemieckiej literatury, niż budowała barierę przed tekstami i kontekstami historycznoliterackimi ${ }^{8}$.

Książki Żygulskiego żyły jeszcze długo po tym, jak w 1960 roku został on przeniesiony na emeryturę. Zresztą jego aktywność naukowa poza uniwersytetem może i dzisiaj imponować. Wniósł Żygulski ważki wkład w edycję dzieł pisarzy niemieckich, oprócz wymienionych przedwojennych tomów BN przygotował bowiem wybór poezji Heinego i Goethego. Jego prace dotyczące Schillera, Hebbla, Kleista czy Ibsena wzbogacały refleksję teatrologiczną. Lata 60. poświęca Profesor na badania i pisanie. W ciągu kilku lat ukazują się trzy całkiem pokaźne monografie ważnych pisarzy niemieckich. Pierwszą z nich jest wydana jako publikacja Komitetu Neofilologicznego PAN w całkiem pokaźnym nakładzie 1000 egzemplarzy monografia Hölderlina9 . Jest to pierwsza (i jak dotąd jedyna) całościowa monografia tego niezwykłego i w Polsce raczej nieznanego poety. Celem publikacji było jak pisał w zakończeniu sam autor - „zapoznanie polskiego czytelnika z obcą mu na ogół osobą i twórczością Hölderlina, wskazanie w ogólnych przynajmniej zarysach zawiłej problematyki tej twórczości oraz tak już bogatej różnojęzycznej literatury przedmiotu. Może wzbudzi ona zainteresowanie naszych badaczy, krytyków, poetów i literatów i zachęci ich do własnych prac nad Hölderlinem i do przekładu jego poezji. Pole jest otwarte ..."10. W znacznej mierze to pole pozostaje otwarte do dzisiaj, choć przyznać trzeba, że po pionierskiej książce Żygulskiego pojawiły się polskie przekłady znaczących utworów niemieckiego poety.

${ }^{7}$ W. Kunicki, op. cit., s. 106. Tłumaczenie - L. Ż.

${ }^{8}$ M. Szyrocki, Z. Żygulski, Geschichte der deutsche Literatur, t. 3: Die deutsche Literatur vom Ausgang des 17. Jahrhunderts bis zu Schillers Tod, Wrocław 1959, 1974 oraz t. 4: Die deutsche Literatur von Schillers Tod bis zur Gegenwart, Wrocław 1961, 1964, 1974.

9 Z. Żygulski, Fryderyk Hölderlin (1770-1843), Wrocław 1964.

10 Ibidem, s. 180-181. 
W 1968 roku publikuje Żygulski opracowanie o Gerhardzie Hauptmannie ${ }^{11}$. Nie osiągnął w nim kunsztu wcześniejszej książki, nowa publikacja bowiem przynosi dosyć standardowy opis życia i twórczości tego dramaturga. Właśnie długoletnie zainteresowanie dramatem i teatrem stało u źródeł zainteresowania Hauptmannem. Narracja książki jest jednak potoczysta i sporo można się z niej dowiedzieć o Hauptmannowskich dramatach. Ta książka ma dzisiaj głównie walor historyczny choćby dlatego, że niemiecki noblista doczekał się szeregu kolejnych opracowań szczegółowych i tomów zbiorowych, wydanych m.in. przez wychowanków Profesora.

Trzecią monografię poświęcił Żygulski Fryderykowi Hebblowi, a została ona wydana także jako publikacja Komitetu Neofilologicznego PAN ${ }^{12}$. Książka ta jest najlepszym z późnych dzieł Profesora. Autor zwieńcza w niej swe długoletnie zainteresowanie Hebblem, już bowiem w 1947 roku zamieścił w „Pamiętniku Literackim” obszerny szkic porównujący twórczość Hebbla i Krasińskiego, a potem wracał do niego niejednokrotnie. Życie i twórczość pisarza przedstawione zostały na tle epoki z dużym znawstwem ówczesnego stanu badań. Żygulski jest w tej pracy empatycznym biografem, wnikliwym interpretatorem dramatów, liryki i Dziennika, rekonstruuje wreszcie światopogląd pisarza. Do dzisiaj ta monografia jest miarodajnym i ciągle jedynym opracowaniem w języku polskim dotyczącym Fryderyka Hebbla.

Profesor Żygulski zmarł 22 października 1975 roku w Łodzi, pochowany zaś został w Krakowie. Tuż przed śmiercią Uniwersytet Wrocławski przyznał mu godność doktora honoris causa, ale choroba uniemożliwiła mu osobisty udział w uroczystości. Jego wielką zasługą było stworzenie historycznoliterackiej szkoły naukowej w oparciu przede wszystkim o badania literatury niemieckiego baroku, przechowanie w czasie trudnym (zamknięcie większości ośrodków germanistycznych w PRL) etosu naukowych badań germanistycznych oraz wykształcenie grona następców, którzy w latach 60. i 70. XX wieku budowali ośrodki germanistyczne na wielu polskich uniwersytetach. Jak pisze Anna Stroka, mistrz wielu germanistów pierwszego pokolenia studiującego po wojnie był człowiekiem „o wielkim czarze osobistym, dużej życzliwości wobec uczniów, miał dar obcowania z ludźmi. Te cechy szły w parze z ogromną wiedzą i sławą wybitnego uczonego, znakomitego erudyty, badacza, który własnym trudem zdobył uznanie"13.

Leszek Żyliński - profesor doktor habilitowany, pracuje w Katedrze Filologii Germańskiej UMK. W 2012 roku ukazała się jego monografia Europa w niemieckiej myśli XIX-XXI wieku.

\footnotetext{
11 Z. Żygulski, Gerhard Hauptmann. Człowiek i twórca, Łódź 1968.

12 Z. Żygulski, Fryderyk Hebbel. Obraz życia i twórczości, Wrocław 1971.

${ }^{13}$ A. Stroka, op. cit., s. 77.
} 